\title{
Închisoarea noastră cea de toate zilele. Despre pedepse și alte sancțiuni
}

\author{
conf. univ. dr. Radu Rizoiu \\ Facultatea de Drept, Universitatea București \\ Motto: I see our freedom in my sight \\ No locked doors, no windows barred \\ No things to make my brain seem scarred \\ Metallica, Welcome Home (Sanitarium)
}

Rezumat: Pornind de la consecințele drastice ale măsurilor de izolare, articolul analizează tipologia sancțiunilor. În ciuda aparentei asemănări din perspectiva restricțiilor impuse libertății individuale, pedepsele sunt diferire de măsurile preventive sau celor de ocrotire. Prin urmare, fiecare măsură luată de Stat și care afectează libertatea individului are un scop diferit și ele nu trebuie confundate. Pe baza acestei delimitări, articolul aplică testul propus la arestul la domiciliu prin prisma propunerilor care vizau generalizarea acestei măsuri pentru infracțiunile de corupție.

Cuvinte-cheie: reguli, pedepse, arest la domiciliu

\section{The everyday prison. On punishment and other penalties}

Abstract: Starting with the harsh consequences of the lockdown, the paper looks into the typology of sanctions. Despite their resemblance in the form of restrictions brought to personal freedom, penalties are different to preventive measures or safety policies. As such, each of these State-led interventions into the personal liberty serves distinctive purposes and should not be confused to one another. Based on this classification, the paper then applies the test to the home arrest and the proposed new rules to make it the penalty of choice for the white collar criminals.

Keywords: rules, penalty, home arrest

În culegerea de nuvele Different Seasons (1982), Stephen King include și textul Rita Hayworth and Shawshank Redemption al cărui subtitlu (în tema culegerii) este Hope Springs Eternal. Cei care nu au citit nuvela s-ar putea să-și amintească un film excelent cu roluri magistrale ale lui Tim Robbins și Morgan Freeman, tradus în limba română drept Închisoarea ingerilor (1994). Fără a povesti o istorie extrem de interesantă, este suficient să amintesc faptul că personajul principal este acuzat de o crimă pe care nu a comis-o și ajunge să ispășească o pedeapsă extrem de lungă într-o închisoare de maximă siguranță. Jocul de cuvinte din subtitlu face trimitere la primăvară și la speranță. Alegoria lui King pare a se potrivi îngrijorător de bine cu actuala situație generată de coronavirus. (Epopeea The Stand dedicată în 1978 de același Stephen King unei pandemii este mult prea distopică pentru a încerca să fac vreo paralelă.) În nuvelă, un om obișnuit ajunge să-și formeze o „familie” în închisoare și să transforme universul penitenciar într-un simplu loc de muncă. Este interesant că unul dintre personaje afirmă că toți deținuții (susțin că) sunt nevinovați (de aici adaptarea românească a titlului).

Pe măsură ce regulile de izolare se prelungesc, tot mai multe voci le aseamănă cu un veritabil regim de detenție. Tot mai des se aude că actuala situație reprezintă un veritabil experiment social extins la nivel mondial. În anul 1971, un grup de psihologi de la Universitatea Standford a realizat un experiment în care un număr de voluntari (studenți) au fost ,„închiși” întro închisoare simulată timp de o săptămână. Repartiția candidaților între rolurile de deținuți și gardieni s-a făcut în mod aleatoriu. Una dintre concluziile experimentului a fost aceea că în doar 
câteva zile comportamentul subiecților s-a schimbat radical, fiecare identificându-se cu rolul atribuit. Cei care se consideră deținuți în propria casă ar putea să se uite la adaptarea cinematografică din 2015 a acestui experiment pentru a vedea diferențele notabile de condiţii.

Și eu cred că asistăm la un experiment social (chiar dacă desfăşurarea lui nu a fost organizată de nimeni) extrem de interesant. Condițiile sunt mult mai reale decât în orice experiment „simulat” și ne permit să observăm o serie de schimbări de comportament. Dar, nepricepându-mă la psihologie, aș vrea să mă îndrept într-o altă direcție: ce ne arată acest experiment cu privire la sancțiuni. Pentru un jurist, sancțiunea este o componentă indispensabilă a oricărei norme. Această abordare are în vedere premisa că regulile (însoțite de sancțiuni) sunt făcute (mai ales) pentru cei care nu le-ar respecta în lipsa impunerii lor de către Stat. Or, singura modalitate de a le impune este să li se asocieze o pedeapsă în caz de nerespectare. De aceea, acest curent susține că o regulă fără sancțiune nu este, de fapt, o adevărată regulă. Alături de alții, eu cred că abordarea este mai nuanțată. Regula se adresează tuturor și spune ce trebuie făcut. Majoritatea vor respecta regula din convingere (adică pentru că au înțeles utilitatea și justețea acesteia). Doar câțiva indivizi o vor nesocoti. Dacă sunt o majoritate, vorbim deja despre o revoluție care sugerează că regula este una injustă și trebuie înlocuită. Atunci când (doar) unii încalcă regula, lor li se aplică o altă regulă (derivată din prima, în sensul că ea are ca ipoteză încălcarea regulii) care spune care sunt consecințele comportamentului contrar regulii. Sancțiunea este deci o (altă) regulă destinată doar celor care ar dori să încalce regulile de bază.

\section{Dar ce am făcut eu? Despre tipologia sancțiunii}

În teoria dreptului se vorbește despre o serie de noțiuni care au în subtext ideea de sancțiune. Astfel, de exemplu, în dreptul penal avem pedepse, măsuri preventive, măsuri de siguranță și măsuri de ocrotire. Nu vreau aici să fac analiza acestor noțiuni, dar o să prezint o serie de ipoteze. (Asemănarea dintre autoritatea statală și cea părintească este, poate, astăzi, forțată, amintind de un paternalism vetust, dar este încă utilă în demersul explicativ.) Imaginați-vă următoarele situații:

(1) Părintele care îi spune copilului care s-a bătut cu fratele lui că este pedepsit să nu mai iasă din casă. (Aici avem o pedeapsă.)

(2) Părintele care îi spune copilului că va sta în camera lui până când se lămurește dacă el este cel care a spart geamul. (Aici avem o măsură preventivă.)

(3) Părintele care îi spune copilului că are scarlatină și că nu poate ieși din casă până nu se însănătoșește, pentru a nu-i îmbolnăvi pe alții. (Aici avem o măsură de siguranță.)

(4) Părintele care îi spune copilului că a fost un accident la Cernobîl și este bine să nu iasă afară pentru a nu se îmbolnăvi. (Aici avem o măsură de ocrotire.)

Se observă cu ușurință că în toate ipotezele (1)-(4), măsura luată este aceeași: copilul nu are voie să iasă din casă. Cu toate acestea, justificarea măsurii este de fiecare dată alta, ceea ce îi modifică însăși natura. Evident că această justificare poate să fie greșită sau pur și simplu inventată. Fanii francizei Cloverfield își aduc aminte cât de puternică poate fi o înșelătorie cu privire la necesitatea izolării. Iar admiratorii lui Joker își amintesc poate despre rolủ ambiguu al Azilului Markham... (Michel Foucault are o analiză extrem de interesantă a paralelelor dintre închisori și spitale în perioada modernității.) În perioada abuzurilor comuniste din anii '50-'60, internarea unor persoane în instituții ,spitalicești” a ascuns uneori încercări de a scăpa de persoane prea vocale împotriva regimului, dar care erau suficient de cunoscute pentru a nu putea „dispărea” pur și 
simplu. Dar nu vreau aici să analizez posibilitatea de abuz de calificare, ci doar faptul că avem o paletă mult mai largă de măsuri decât pare la prima vedere.

Interesant este faptul că toate aceste măsuri arată (în plan fizic) la fel pentru individ: este precum copilul nu are voie să iasă din casă. Din punct de vedere psihologic, însă, raportarea individului la fiecare dintre măsuri este diferită. Iar binomul care subliniază aceste diferențe este cel dintre interesul individului și cel al societății. Aici, modul de evaluare al acestor interese trebuie să vină de la societate pentru că aceasta este singurul actor cu o doză de obiectivitate dată de multitudinea de indivizi (organizați în instituții). Dacă ne-am raporta la percepția individuală, contingențe personale pot schimba calificarea în mod aleatoriu. (De exemplu, o persoană care are o înclinare psihologică mai accentuată către teorii ale conspirației se va considera mai tot timpul pedepsit, deși nimeni nu intenționează acest lucru.) Astfel, putem să „dozăm” amestecul dintre interese astfel:

(1’) La pedeapsă, interesul societății (de a-l izola pe vinovat) este predominant și principal.

Prin aceasta vreau să spun că măsura este una care este (aproape) exclusiv în beneficiul societătiii și în detrimentul persoanei pedepsite. (Este adevărat că se vorbește și de rolul educativ al pedepsei, dar scopul reeducării este oarecum secundar.) Rațiunea constă în aceea că persoana în cauză a greșit deja (a încălcat regula) și, implicit, și-a asumat consecințele. Pedeapsa este considerată de unii autori (mai ales nordamericani) ca „preț” al încălcării regulii. Încălcând regula, contravenientul a acceptat să plătească acest „preț”.

(2’) La măsura preventivă, interesul societății (de a-l izola pe vinovat) este tot predominant, dar este relativ.

Relativizarea vine din nevoia de a explica limitele acestei izolări în funcție de interesele celorlalți indivizi din societate. În definitiv, până la condamnare, individul trebuie să fie prezumat nevinovat, ceea ce face ca măsura preventivă să fie o excepție. Prin urmare, de vreme ce nu știm că a fost încălcată regula de către acea persoană, nu putem să o pedepsim (încă). Dacă o lăsăm liberă, însă, este posibil ca alte reguli să fie încălcate, inclusiv să o expunem unei reacții violente din partea altor persoane. Chiar și în această din urmă ipoteză, izolarea suspectului nu are în vedere interesul acestuia, ci interesul societății ca altă încălcare (violența contra suspectului) să nu se producă. În orice caz, măsura preventivă nu trebuie să devină o regulă şi nu trebuie luată pentru că așa este mai comod pentru anchetatorul faptelor (să îl aibă pe suspect „la îndemână” și „sub presiune").

(3’) La măsura de siguranță, interesul preponderent este al individului de a fi readus la standardele care îi permit o reintegrare în societate, iar în subsidiar este interesul celorlalți indivizi de a fi protejați.

Vedem deja o schimbare de accent: interesul avut în vedere nu mai este al societății (în ansamblul său), ci al unui individ (sau grup de indivizi). Este drept că de multe ori individul însuși nu-și dă seama că este în interesul său să fie izolat (internat, tratat) și această măsură îi este impusă de stat. Dar măsura luată trebuie să fie una curativă, iar nu punitivă. Statul este interesat de bunăstarea individului. În același timp, statul are responsabilitatea de a se îngriji ca și ceilalți indivizi să fie protejați de eventualul pericol (involuntar) adus de existența unui individ afectat.

(4') La măsura de ocrotire, interesul este (aproape) numai al individului de a fi protejat de restul societății sau de elemente externe care îi pot face rău.

Aici măsura izolării (obligatorii) este cel mai greu de justificat. În principiu, un individ este răspunzător de deciziile pe care le ia cu privire la persoana sa. Dar atunci când acele decizii pot afecta societatea (și instituțiile sale), lucrurile se complică. Una dintre problemele etice extrem de dificile este de a distinge între sinuciderea 
unei persoane în propria locuință și cea realizată prin aruncarea în faţa metroului. Dincolo de tragismul ambelor ipoteze, cea de-a doua mai aduce un element: costurile (economice și emoționale) aduse societății de oprirea circulației metroului și de șocul provocat celorlalți călători. Iată cum interesul societății se poate insinua pe nebănuite acolo unde (aparent) se apără doar un interes individual.

Este drept că marea difícultate este dată de agentul care decide ce este mai bine pentru individ, respectiv pentru societate în ansamblul său. Dar aici intrăm pe tărâmul teoriilor politice cu privire la rolul guvernării și al guvernanților. Așa că voi presupune că statul (și autoritățile sale) își fac treaba și identifică în mod corect aceste interese.

Acum, pe schema propusă de mine (care nu este nici pe departe originală și simplifică lucrurile destul de mult), diferitele măsuri luate de autorităţi în timpul stării de urgență pot fi gradate în funcție de gravitate. Astfel, sancționarea acelor persoane care au încălcat regulile impuse în timpul carantinei vor fi veritabile pedepse. De exemplu, dacă se dovedește că o persoană (știind sau bănuind că este infectată) a continuat să circule în comunitate fără a-și lua vreo măsură de protecție, ea va putea fi condamnată pentru infracțiunea de răspândire a bolilor. Dacă doar se suspectează că au existat îmbolnăviri cauzate de acea persoană, până la judecarea cauzei, persoana poate fi supusă unei măsuri preventive de izolare (carantină).

În schimb, persoanele care sunt infectate sunt obligate să stea în carantină pentru o anumită perioadă (considerată a fi perioada de contagiune), ca o măsură de siguranță. Iar dacă o persoană prezintă anumite probleme de sănătate care îi afectează sistemul respirator sau pe cel imunitar, măsura autoizolării va fi una de ocrotire. În acest din urmă caz, interesul statului este de a evita un blocaj al sistemului de sănătate care nu este pregătit să trateze simultan un număr ridicat de cazuri de infectare. Este drept că toți vor sta în casă, dar din motive diferite.

\section{Despre arestul la domiciliu}

Aceste distincții ridică însă o altă întrebare: dacă toți suntem obligați să stăm în casă, de unde ne dăm seama cine este pedepsit și cine nu? Problema a fost pentru un scurt moment în această nebunie în lumina reflectoarelor atunci când a fost ,reînviat” un mai vechi proiect legislativ care își propunea să generalizeze posibilitatea ispășirii pedepsei penale prin așa numitul ,arest la domiciliu". Fără a intra în detalii, o variantă a proiectului propunea ca unele persoane să execute pedeapsa închisorii (după ce au fost condamnate definitiv, adică pedepsite) prin izolarea în propria locuință (cu varianta izolării doar în afara orelor de program la serviciu, când persoana condamnată se putea deplasa la locul de muncă).

În actualul context, cred că ar putea fi deschisă o dezbatere veritabilă cu privire la caracterul de sancțiune al acestei modalități. Acum, când majoritatea persoanelor sunt supuse unui regim similar, oare nu am putea să vedem în ce măsură arestul la domiciliu este o veritabilă sancțiune? O persoană condamnată pentru o faptă penală și care ar alege această variantă se va afla exact în situația în care ne aflăm acum cei mai mulți dintre noi, care nu am făcut nimic reprobabil. Este oare echitabil?

O întrebare și mai grea este aceea care are în vedere o altă măsură propusă. Ca urmare a răspândirii accelerate a virusului în spațiile închise unde locuiesc comunităţi extinse, s-a argumentat că deținuții ar trebui eliberați (pe durata pandemiei) și plasați în arest la domiciliu. (Nu discut aici eficiența unei măsuri de izolare care nu poate fi verificată în mod obiectiv „în teren”. Să presupunem că persoana eliberată respectă măsura arestului la domiciliu.) Oare o astfel de persoană mai poate fi considerată ca fiind în executarea unei pedepse, de vreme ce are același tratament ca și restul persoanelor (nevinovate)?

Aici pot fi găsite o serie de nuanțe: izolarea într-o garsonieră de bloc (fără balcon) poate fi mult mai restrictivă (psihic) decât izolarea într-o vilă cu o curte considerabilă. În plus, izolarea 
împreună cu alte persoane (membrii familiei) mai este oare o izolare cu efect punitiv? A sta cu cei dragi în propria locuință mai este oare o pedeapsă? (Statisticile cu privire la creșterea ratei violenței domestice poate oferi un indiciu pentru răspunsul la această întrebare.) Altfel spus, nu cred că o măsură care astăzi este impusă tuturor ca o măsură de ocrotire poate deveni o pedeapsă generalizată pentru cei care au săvârșit o infracțiune. Așa cum nu cred că astăzi suntem cu toții ținuți de Guvern ,în arest”, tot așa nu cred că „,arestul la domiciliu” este o măsură punitivă eficientă.

În definitiv, A man's home is his castle. Domiciliul este considerat locul unde individul se simte cel mai bine, unde este protejat de orice pericol. (Butada că majoritatea accidentelor se întâmplă acasă este distractivă tocmai prin încercarea de a nega acest adevăr.) Poate un spațiu al siguranței personale să fie transformat într-un spațiu al pedepsei? Parafrazând titlul care face referire la o celebră carte, în care Ion Ioanid explică experiența sa penitenciară din închisorile comuniste, nu ar deveni atunci închisoarea casa noastră cea de toate zilele? În loc să ne simţim la închisoare ca acasă (precum Andy Dufresne și Red, eroii din Inchisoarea îngerilor) ne vom simți acasă ca la închisoare?

Materialul a fost publicat în revista online a Facultății de Drept, $\underline{\text { AUBD - Forum Juridic nr. }}$ $\underline{1 / 2020 .}$ 